\title{
The Evaluation of Genre-based Approach Cycle Implementation in Tasks Organization of Curriculum 2013 English Textbook for $9^{\text {th }}$ Grade Students
}

\author{
Anggi Angraeni*, Yanty Wirza \\ English Language Study Program, Universitas Pendidikan Indonesia \\ ${ }^{*}$ Corresponding author. Email: anggiangraeni@upi.edu
}

\begin{abstract}
Bahasa Inggris-Think Globally, Act Locally was developed by Puskurbuk and has become the standardized book for ninth grade English learning in national schools in Indonesia. Thus, this book is expected to be averagely applicable to use in most schools in the country. However, at an initial interview, the teachers complained that this book suddenly brings students to analyse function, structure, and the grammatical aspect. It becomes problematic since the students at the school have no background knowledge of the text. The teachers believe that their students need to overview the function and other distinguishing aspects of the text. Besides, since the book is claimed to be developed through a text-based approach, this study seeks to evaluate if the contents in all chapters of the book have been organized coherently with the genrebased approach learning cycle proposed by Hammond. By the identification, it was found that none of the textbook chapters involves complete steps of the process. Despite the theories that in some circumstances teachers can move forward, backward, or skipping steps in the application of the genre-based approach, the characteristics of the students where the study is made did not fit for skipping procedure. Besides, it is also discussed students' and teachers' perceptions towards the skipping step. Moreover, to avoid this absence affecting the general result of the pedagogical process negatively, completion of tasks and materials can be added to the textbook.
\end{abstract}

Keywords: ELT material, genre-based approach, textbook evaluation

\section{INTRODUCTION}

This book is a recommended book for implementing Curriculum 2013 commonly used in junior secondary school level of national schools in Indonesia. It is claimed to be coherently developed to the contents of the current Indonesia national curriculum of English at junior secondary school level based on Indonesia Ministry of Education and Culture's decision number 922018 regarding the foundation of the 2013 curriculum for elementary and junior secondary school level.

In Sumedang Regency, under the local education agency, schools must buy and use this textbook. The usage of other books is acceptable, as additional references, if the schools or individuals are financially able to afford them. This book plays as the primary source in ELT on the level since the culture and financial situation of the society has not put the needs of literacy as a priority. The intention from the authority, parents, and stakeholders to make use of supporting learning sources is limited. So, most students find this textbook as their primary and only source of English learning. Simultaneously, some teachers combine this book with other relevant books when they find that they need support unavailable in this textbook.

Moreover, since the Covid-19 pandemic stroke, the book's role is getting central because distance learning implementation limits teacher-student interaction, including teachers' transferring knowledge unavailable in the book.

Thus, since this is the broadest used English textbook in the area and has a central role in today's learning, it is essential to evaluate its applicability. By evaluating this book, it is expected to improve the book's quality and improve the quality of the ELT process and result. Because from a particular perspective, a textbook can sometimes be defined as an agent of change (Hutchinson \& Torres, 1994).

Teachers complain that this book suddenly brings students to analyse function, structure, and grammatical aspects when they have no background knowledge of the field. From an initial interview with the teacher, a problem was found. The teacher argued that all chapters in this book are started with modelling. This fact becomes 
problematic since the students at the school have no background knowledge of the text. The teacher believes that students need to overview the function and other distinguishing aspects of the readers before involving the students in the texts' technical work. Thus, students can practice meaningful learning. To anticipate this, the teachers provide themselves with another supporting book, but the students do not.

In the textbook's preface, the authors claimed that they use a text-based approach to develop this book.

\section{Kata Pengantar}

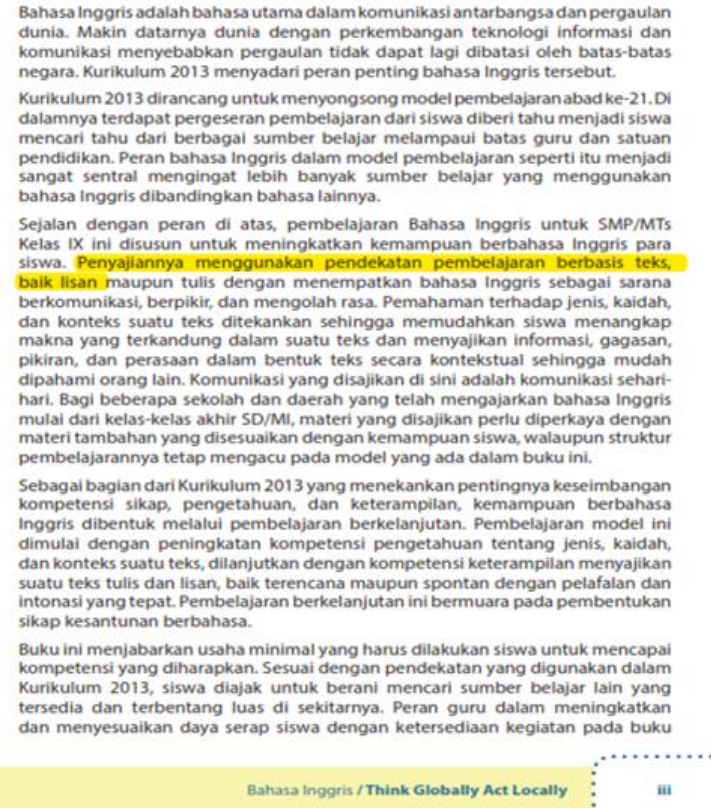

Figure 1 Preface of Student Book: Think Globally, Act Locally- taken from Wachidah, Diyantari, and Gunawan (2018)

A genre-based approach placed great emphasis on the relationship between text-genres and their contexts (Hyon, 1996). In doing so, it aimed to help students become effective participants in their academic and professional environment as well as in their broader communities

However, the teacher guidebook does not show the genre-based approach model of implementation. It shows that the organization of tasks and materials of the book support the scientific learning approach. It can be seen from the steps described in the teacher book. The steps were observing, questioning, experimenting, associating, and networking or communicating. Those are steps of scientific learning approach (Shofwan, 2017).
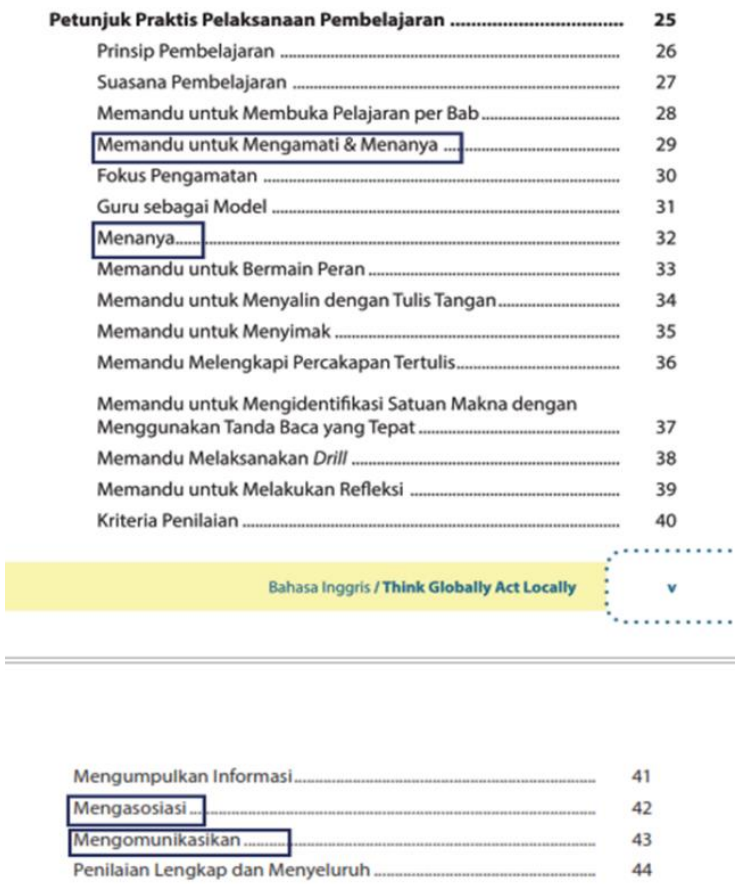

Figure 2 Teacher book of guidelines: Think Globally, Act Locally - taken from Wachidah, Khatimah, and Dyantari (2018)

Furthermore, in the Indonesian context, where English is considered a foreign language, the use of the genrebased approach model has to be modified (Alwasilah, 2013). It urges the necessity to recontextualize. Other findings indicated that the genre-based pedagogy in Indonesian EFL classrooms had been recontextualized only in parts. If the genre-based pedagogy is not recontextualized appropriately, it may weaken the attainability of genre pedagogy's main goal, which is to uphold social justice through equal distribution of knowledge (Kartika-Ningsih \& Gunawan, 2019). The limitation of the textbook used in is possibly one of the factors which lead to this partial recontextualization.

To respond to the issue, there are two aims of this study. First, it aims to evaluate the textbook activities' organization's consistency using the genre-based approach learning cycle. There are some models of the genre-based approach learning cycle. They vary in steps. However, the model is proposed by Hammond (1992). It is chosen as the framework since it involved detailed steps that would fit learners' beginner level. 


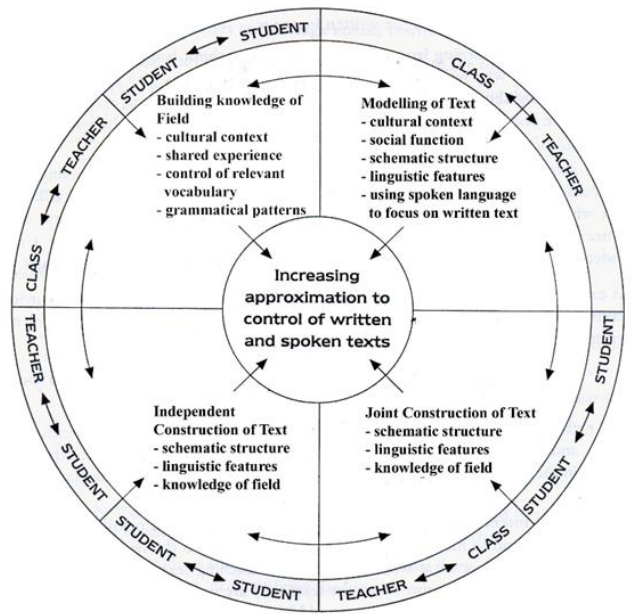

Figure 3 Model of Genre-based Approach Cycle- Taken from Hammond (1992)

In the first step, building knowledge of the field, teachers should identify some aspects. Those are: (1) what the area is, (2) what part of it we will be explored, (3) what the students already know about it, (4) what experiences/activities will be part of the exploration, and how the teachers will organize and record information from the activities (Rothery, 1996, p. 102, cited in Emilia, 2010). The aspects are attained through particular tasks such as guided discussions about the area of study, handson activities such as experiments, excursions, brainstorming, mind mapping, research tasks such as jigsaw tasks, note-taking, vocabulary building (Derewianka \& Jones, 2016).

The second step is the modelling of the text. At this step, the context is explored, and explicit instruction is delivered to the students. Through this step, the students are expected to become familiar with the genre. They learn about the purpose, overall structure, and linguistic features of the text type. They deconstruct the text to gain a better understanding of the content of the components of the text (Gibbons, 2007).

The third step is the joint construction of the text. The emphasis of this step is for the students to recognize writing using content and language. In this step, the teacher and the students work together to create a text with the teacher lead the discussion and facilitate the text's creation. Teachers must not dominate the composition of the text (Gibbons, 2007).

Moreover, the last step of this cycle is independent construction. During the independent construction, the teacher's guide the students to compose their writings independently. They will follow a model for less confident students, but it will involve a creative turn and an expansion of their collection (Derewianka \& Jones, 2016).

This study aims to seek justifications through theoretical analysis and the analysis of teachers' and students' perceptions. Because materials writing is most effective when it is turned to the needs of a particular group of learners (Tomlinson \& Masuhara, 2010). It is believed that most students at the school where this book has been used started to learn English in their 7th grade. It means that the ninth graders have just studied English for less than three years with language proficiency level A1A2 (beginner-elementary). This fact should also be considered by teachers when they are about to skip one of the cycle steps.

Besides, it is also discussed how the choice of skipping any steps of a cycle might be disadvantageous and advantageous for teachers from a different perspective (Littlejohn, 1992). Finally, recommendations are given to improve the textbook and the process of teaching and learning of the book users (students and teachers).

\section{METHOD}

An initial piloting interview had been held before the study. From the results of the interview with two English teachers in a school, it was found that there is a gap between the contents of the book and the needs of its users (teachers and students).

From the piloting interview, it was also decided that two English teachers and 33 ninth-grade students at that school were purposively selected as the participants of this study.

Also from the piloting interview, it is found that the book is claimed to be developed through a text-based approach, this study seeks to evaluate if the tasks and materials in all chapters of the book have been organized coherently with the genre-based approach learning cycle proposed by Hammond et al. (2001). There are four steps in the teaching-learning cycle which are virtually based on genre approach. They are: (1) building knowledge of the field, (2) modelling of the text, (3) join the construction of the text, and (4) independent structure of the text (Hammond, 1992).

There are 11 chapters of the book. The steps of the GBA cycle are identified from the learning tasks and materials of the eleven chapters. The data are presented in the form of table.

From the identification, it was analysed the missing steps of the genre-based approach cycle. Next, a descriptive discussion based on data and theories was delivered.

Despite the theories that in some circumstances teachers can move forward, backward, or skipping steps in the application of genre-based approach (Pujianto, Emilia, \& Ihrom, 2014), it was analysed whether the practical situation in the field fits the skipping procedure.

For this analysis, teachers' and students' perceptions of the skipping steps were gathered from the questionnaire's responses and interviews. The questionnaire and interview questions were self-developed by the steps of the genrebased approach cycle. Besides, from the perspective of the 
book developer, it is also discussed how the choice of skipping any steps of the cycle might be disadvantageous and advantageous for teachers and students from a different point of view (Littlejohn, 1992).

The questionnaire was in an online form. It was shared with the 33 participants via a link. Those who concisely agree to be participants were asked to respond to the questions and statements within a week. The responses were later managed, and the data were presented in the form of charts that show their perception in: (1) the role of the book, (2) the difficulty level to follow the flow, and (3) the aspects that cause the difficulties. The charts were analyzed descriptively and theories related to the topic are elaborated by the discussion.

To triangulate the data, the two teachers' perspectives were investigated. One-on-one interviews were held for the aspects discussed above to assure that the statements were independent and show teachers' true perception toward the issue. They were also semi-structured. Some questions that question their perception of the book content and how an ideal book should be were prepared and some adlibs were added when an in-depth investigation was needed.

Each interview took 20 minutes. It was recorded. The records were transcribed, and the results were coded by three categories: (1) The completion of the content (Tasks and materials), (2) Teachers' effort to fill the gaps between the book contents and students' needs, and (3) Teachers' recommendation for book improvement. The data were in the form of a description.

Data from the two sources, questionnaire, and survey, were then elaborated descriptively with available theories: theories of teaching material development, theories of genre-based approach for teaching English, and how are the implications to English curriculum in the Indonesian context.

By the discussion, we can conclude the core of the issues. From which recommendations were formulated as an alternative solution, so that this absence of cycle steps will not negatively affect the general result of the pedagogical process.

\section{FINDINGS AND DISCUSSION}

The findings and discussions cover the summary of the textbook evaluation, the proposed revision, and the paper's recommendation.

\subsection{Summary of Evaluation}

By analysing the book's content, we can identify the availability of each step of the genre-based approach cycle as in Table 1.
Table 1. Identification of GBA Cycle Steps

\begin{tabular}{|c|c|c|c|c|}
\hline \multirow[b]{2}{*}{$\begin{array}{l}\text { Chapter } \\
\text { Number }\end{array}$} & \multicolumn{4}{|c|}{ Stages of The GBA Cycle } \\
\hline & $\begin{array}{l}\text { Building } \\
\text { Knowledge of } \\
\text { The Context }\end{array}$ & $\begin{array}{l}\text { Modeling/Deconstructing } \\
\text { The Text }\end{array}$ & $\begin{array}{c}\text { Joint } \\
\text { Construction } \\
\text { of The Text }\end{array}$ & $\begin{array}{l}\text { Independent } \\
\text { Construction of } \\
\text { The Text }\end{array}$ \\
\hline 1 & & $\sqrt{1}$ & $\sqrt{ }$ & \\
\hline 2 & & $\sqrt{ }$ & $\sqrt{ }$ & \\
\hline 3 & & $\sqrt{ }$ & $\sqrt{ }$ & \\
\hline 4 & & $\sqrt{1}$ & $\sqrt{ }$ & \\
\hline 5 & & $\sqrt{ }$ & $\sqrt{ }$ & \\
\hline 6 & & $\sqrt{ }$ & $\sqrt{ }$ & \\
\hline 7 & & $\sqrt{ }$ & $\sqrt{1}$ & $\sqrt{ }$ \\
\hline 8 & & $\sqrt{1}$ & $\sqrt{1}$ & \\
\hline 9 & & $\sqrt{ }$ & $\sqrt{ }$ & \\
\hline 10 & & $\sqrt{ }$ & & \\
\hline 11 & & $\sqrt{ }$ & $\sqrt{4}$ & \\
\hline
\end{tabular}

The full cycle of genre-based approach by Hammond (1992) covers the steps: (1) building knowledge of the field, (2) modelling of the text, (3) joint construction of the text, and (4) independent construction of the text (Hammond, 1992).

From the identification table of the textbook tasks and materials analysis, it is shown that there is no chapter of the textbook that demonstrates the complete cycle of GBA. Nine out of eleven chapters only cover two steps, the modelling/deconstructing and the joint construction. None of the chapters involves the activity of building knowledge of the text/context. Only one chapter consists of the action of Independent Construction (Chapter 7).

Thus, it urges to know teachers' and students' perception towards the procedure of skipping and excluding steps of the cycle.

\subsubsection{Building Knowledge of The Fields}

To evaluate if the decision to skip and exclude the steps suits the book users' needs, the questionnaire instrument has been analysed. It is found that the respondents are active users of the textbook. 33 students participated. They have been using the book for 4-6 months.

Very useful Helpful Less helpful Not useful

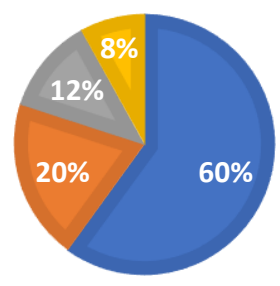

Figure 4 Students' perception of the usefulness of the book

Twenty-one participants $(60 \%)$ found the textbook very useful for their learning since it became their primary and only source for English learning. Seven participants found the textbook helpful (20\%); four participants 
thought it is less useful (12\%), and three participants (8\%) stated that it is not beneficial for their learning. It means that $80 \%$ of participants assume this textbook is essential (very). It becomes a piece of evidence that students' perceptions of this book's role are central to their learning. For its central role, this textbook should own the criteria of an ideal textbook such as: has a common core of needs, good preview-good catch-up, well-presented, and adaptable (O'Neill, 1982).

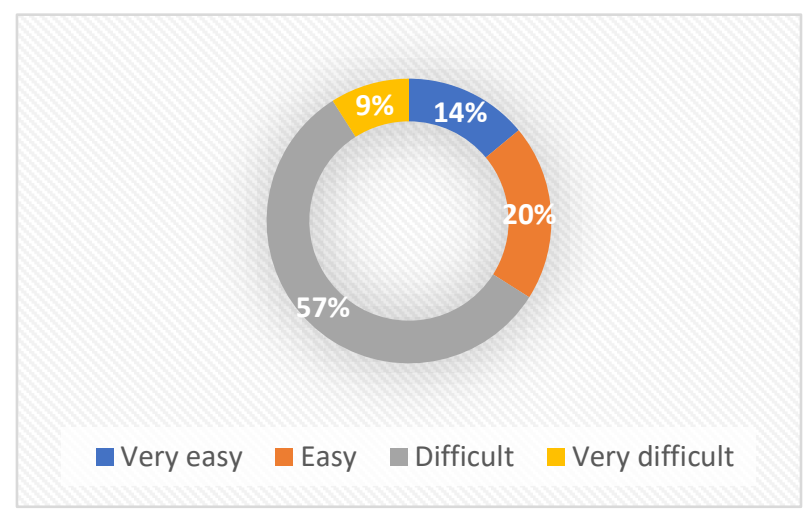

Figure 5 The difficulty level of book usage

For the difficulty of following the task of the book, five participants (14\%) found it very easy to follow. Seven participants $(20 \%)$ stated that it is easy to follow. Twenty participants $(57 \%)$ found the steps challenging to follow, and 3 participants (9\%) consider the book's tasks extremely hard to follow. We can conclude that $66 \%$ of the participants have difficulties following the book's steps, both the materials and the tasks. The participants' elaboration found that they do not understand the instruction, unfamiliar vocabulary, complicated tasks, and uncoherent scaffolding steps. It is consistent with Vygotskyan principles which consider scaffolding as an effective strategy in learning through GBA (Lin, 2006). He claimed that learning sentence-level structure is still crucial since it is a part of the GBA model, the building knowledge of the topic when the student intake suggests the needs. For the case of this study, the student intake suggests this need to apply the cycle step.

This finding calls for the need to recontextualize the EFL context's genre-based approach (Kartika-Ningsih \& Gunawan, 2019). In choosing the appropriate GBA cycle, book developers need to be aware that English is a foreign language in Indonesia. Besides, since this is a recommended book, the developers should analyse the average students' language proficiency and cognition level. The cycle should not be the same as it is used in first-language English countries where GBA are widely used, such as Australia and America. The three steps cycle (modelling, joint construction, independent construction) possibly effective in those countries, but in most schools in Indonesia, at least at the school where the data of this research are taken from, the four steps GBA cycle can be more effective.

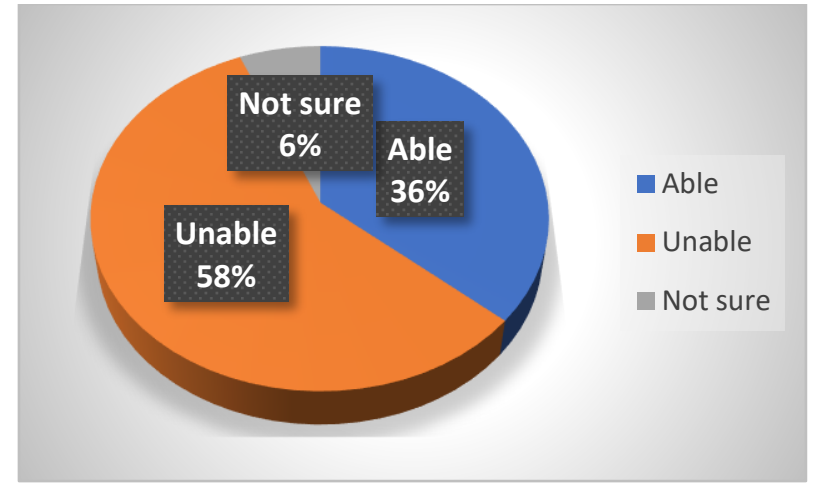

Figure 6 Students' ability to use the book independently

Meanwhile, as the responses to whether they can use this textbook independently during distance learning, 10 participants $(36 \%)$ responded positively. Sixteen students $(58 \%)$ answered they could not use the book independently. At the same time, nine students $(6 \%)$ are not sure if they can/cannot use the book independently. It means that more than half of the participants assume they cannot use the book independently. The rest stated that they need help to do the tasks and find supporting materials from their teachers, families, classmates, or internet browsing. It is also found that 12 participants $(34,3 \%)$ use dictionaries while using the textbook. However, the rest $68,6 \%$ do not have any dictionary. The use of a dictionary can be evidence that students find difficulty in understanding vocabulary. This issue can be minimized if the step of building knowledge is available since vocabulary building is one of the step's tasks.

Teacher guidance is still unavoidably needed for students' knowledge constructions, especially when we discussed students' English proficiency and developmental levels (Schwarz, Dreyfus, Hadas, \& Hershkowitz, 2004).

It is related to the notion of whether they have background knowledge of the field before they start their learning, there are teachers' and students' perceptions. Both teachers' percept themselves have background knowledge.

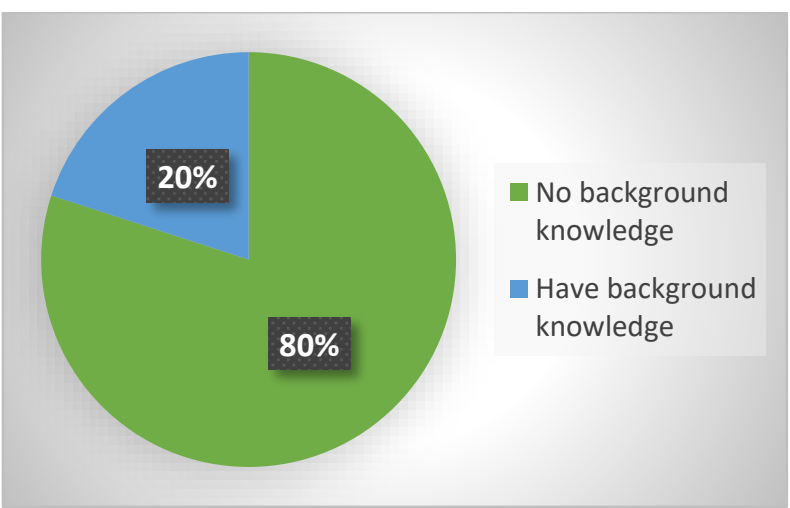

Figure 7 Students' perception of the background knowledge of the text 
Twenty-six students $(80 \%)$ percept that they had not had any background knowledge of the field before starting their learning. The participants argued that they need to know the overview of the genre studied (purpose, generic structure, and grammatical features) and frequently used vocabulary translations. They stated that the tasks and additional materials from their teachers help them to have an overview of the genre. Without teachers' guidance, they cannot follow the flow of the book.

Even with teacher guidance, the availability of tasks reflecting the step of background knowledge of the field is still necessary. This book does not suit the participants' needs considering that the participants are at beginner level in EFL proficiency. They are below the lower threshold of proficiency. In this circumstance, teaching linguistic knowledge is sufficient for them to be able to operate the language (Ridgway, 1997). So, skipping this step does not meet the needs of the book users.

\subsubsection{Independent Construction}

The fact that there is only one chapter that shows a task that represents the step of independent construction is rather problematic. Language functions as both communication and literacy tools. From the perspective of basic literacy, writing skill is as important as reading skill. Writing skill functions to disseminate ideas. We do not call it literacy when it does not involve the process of transferring ideas (Mkandawire, 2018).

The teachers were aware that the English curriculum in the Indonesian context expects to implement behavioural outcomes. Mager (1962) cited by Richards stated that behavioural objectives hold three characteristics: (1) they state behaviours to perform, (2) describe the condition where we hope the performance to occur, (3) They describe the degree of an expected standard (Richards, 1984). So, doing writing tasks how teachers can measure students' skills in one text genre.

Still from the perspective of curriculum, the skipping of independent constructions does not support the concept of literacy (Cope \& Kalantzis, 2011) (Permendikbud 23, 2015). Since in the Indonesian context we view English as a Foreign Language, so teaching language skills including writing skills explicitly, is very important (Cope \& Kalantzis, 2011).

Learning from a study in the literacy of foreign language in South Korea, reading and writing proficiency are correlated. Extensive reading is, of course, significantly improve writing skills. Nonetheless, the extensive writing activity also affects students' improvement in reading skills (Lee \& Schallert, 2016).

Therefore, if English is treated as a tool for literacy, the process of learning English should not stop in enhancing reading skills. We also need attention to writing skills, including in the development of book tasks and materials.

\subsection{Proposed Revision}

Revision is needed to demonstrate a complete cycle of the genre-based approach in additional content, materials, and task.

Although the model is in a circle, and it allows the cycle to begin from any steps, or to forward/skip step(s) of the process (Pujianto et al., 2014), but there should be a fair justification of why we skip any of the steps. Since, in this context, the students learn English as a foreign language, and English in the structure of the Indonesian curriculum has only been started to learn in seventh grade, it needs more rationales to skip the first step -building knowledge of the context- and exclude most of the steps of independent construction.

This students' perception is in line with what has been discussed by Derewianka and Jones about the possible task to build students' knowledge of the field: guided discussions about the area of study, hands-on activities such as experiments, excursions, brainstorming, mind mapping, research tasks such as jigsaw tasks, note-taking, vocabulary building (2016). The perception also proves that skipping the step of building knowledge of the field in this specific environment is impossible.

Whereas, as the response to the interview question of whether independent construction is needed, both teachers positively. They argued that since the curriculum's competence outcomes are behavioural skills, they expect their student to produce the language's function in written or oral form by the end of their lesson. So, excluding the independent construction step does not meet the EFL curriculum's target at the junior secondary school level, to be precise on the skill dimension.

Aspects to focus on at this step include:

- planning text structure and ideas

- drafting sentence construction and vocabulary

- editing spelling and punctuation (Derewianka, 2003).

\subsection{Recommendation}

As a recommendation to the teachers, initiatives to complete the content and tasks are needed. So, students can demonstrate a complete cycle of English learning through the genre-based approach. The materials can be added by combining other books, online resources, teacher-developed materials, or a mobile application.

To revise this book, it is recommended to add materials to support building knowledge of the field step. Besides, all chapters also need an additional task to accommodate the independent construction step. 


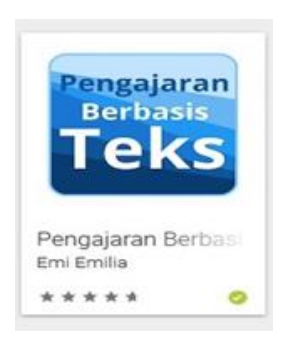

Figure 8 Mobile Application for ELT with Genre-based Approach. Taken from https://play.google.com/store/apps/details?id=com.emie milia.TextBased

\section{CONCLUSION}

It can be concluded that the textbook evaluated was not comprehensively developed through the cycle of the genre-based approach by Hammond (1992). There are only two out of four steps elaborated on the materials and tasks in all 11 book chapters.

In the context where the data was taken, skipping and excluding the steps' procedures cannot be justified. It is shown by the questionnaire responses from both teachers and students. The percept that the absence of the cycle steps brought difficulties in using the book if no supporting materials are given by the teachers or be sought from various other sources by the students independently.

From one side, it is a limitation, but from another side, this can be an opportunity for teachers to improvise and to train their students to become critical and autonomous through appropriate teaching and learning strategies.

As a recommendation for the book developer, this book can have added ups to the materials and tasks that support the complete steps of the genre-based approach cycle. Whereas for the teachers as the users of this book, they should continue what they have done so far by giving an overview of the genre and use various strategies to build students' background knowledge of the field, including their vocabulary building.

\section{REFERENCES}

Alwasilah, C. (2013). Policy on foreign language education in Indonesia. International Journal of Education, 7(1), 1-19.

Cope, B., \& Kalantzis., M. (2011). Introduction: How a genre approach to literacy can transform the way writing is taught. In B. Cope \& M. Kalantzis (Eds.), The powers of literacy: A genre approach to teaching writing. Routledge.

Derewianka, B. (2003). Trends and issues in genre-based approaches. RELC Journal, 34(2), 133-154.

Derewianka, B., \& Jones, P. (2016). Teaching language in context. Oxford University Press. 198 Madison Avenue, New York, NY 10016.
Emilia, E. (2010). Pembelajaran bahasa melalui genre teks [unpublished article]. Bandung: Universitas Pendidikan Indonesia.

Gibbons, P. (2007). Writing in a second language across the curriculum. BILINGUAL EDUCATION AND BILINGUALISM, 61, 195.

Hammond, J. (1992). English for social purposes: A handbook for teachers of adult literacy [unpublished dissertation]. National Centre for English Language Teaching and Research, Macquarie Univ.

Hutchinson, T., \& Torres, E. (1994b). The textbook as agent of change. ELT Journal, 48(4), 315-328.

Hyon, S. (1996). Genre in three traditions: Implications for ESL. TESOL Quarterly, 30(4), 693-722.

Kartika-Ningsih, H., \& Gunawan, W. (2019). Recontextualisation of genre-based pedagogy: The case of Indonesian EFL classrooms. Indonesian Journal of Applied Linguistics, 9(2), 335-347.

Lee, J., \& Schallert, D. L. (2016). Exploring the readingwriting connection: A yearlong classroom-based experimental study of middle school students developing literacy in a new language. Reading Research Quarterly, 51(2), 143-164.

Lin, B. (2006). Genre-based teaching and Vygotskian principles in EFL: The case of a university writing course. Asian EFL Journal, 8(3).

Littlejohn, A. P. (1992). Why are English language teaching materials the way they are? Lancaster: University of Lancaster.

O'Neill, R. (1982). Why use textbooks? ELT Journal, 36(2), 104-111.

Mkandawire, S. B. (2018). Literacy versus Language: Exploring the Similarities and Differences. Journal of Lexicography and Terminology, 2(1), 37-55.

Pujianto, D., Emilia, E., \& Ihrom, S. M. (2014). A process-genre approach to teaching writing report text to senior high school students. Indonesian Journal of Applied Linguistics, 4(1), 99-110.

Ridgway, T. (1997). Thresholds of the background knowledge effect in foreign language reading. Belfast: Queen's University.

Shofwan, M. I. (2017). The use of scientific approach in teaching English as a foreign language in SMPN I Jakarta. Edulingua: Jurnal Linguistiks Terapan Dan Pendidikan Bahasa Inggris, 4(1).

Schwarz, B., Dreyfus, T., Hadas, N., \& Hershkowitz, R. (2004). Teacher guidance of knowledge construction. International Group for the Psychology of Mathematics Education, 4, 169-176. 
Tomlinson, B., \& Masuhara, H. (2010). Research for materials development in language learning: Evidence for best practice. KOTA: Bloomsbury Publishing.

Wachidah, S., Diyantari, Y., \& Asep Gunawan. (2018). Buku pegangan siswa kelas 9. Puskurbuk.

Wachidah, S., Khatimah, Y., \& Diyantari, Y. (2018). Buku guru Bahasa Inggris. Puskurbuk. 